\title{
A COMPARISON OF METHODS USED IN ESTIMATING MISSING RAINFALL DATA
}

\author{
R. P. De Silva ${ }^{1}$, N.D.K. Dayawansa ${ }^{1}$ and M. D. Ratnasiri ${ }^{1}$
}

\begin{abstract}
Precipitation or rainfall (in tropics) is an important climatic parameter and the studies on rainfall are commonly hampered due to lack of continuous data. To fill the gaps (missing observations) in data, several interpolation techniques are currently used. However, the lack of knowledge on the suitability of these methods for Sri Lanka is a practical problem. In view of this problem, this study is aimed at comparing a few selected methods used for the estimation of missing rainfall data with a new method introduced by the authors to determine their suitability in Sri Lankan context. The methods studied were Arithmetic Mean (Local Mean) method, Normal Ratio method and Inverse Distance method. The new method introduced by the authors is named as Aerial Precipitation Ratio method.
\end{abstract}

In this approach, rain gauging stations where complete monthly rainfall data sets are available were selected in such a way that the selected stations represent each of the seven major Agro-ecological zones of Sri Lanka. This selection procedure of stations makes it possible to generalize the results to the entire country. The period of data ranged from 15 years in the case of mid country intermediate zone to 28 years Up country intermediate zone and Mid country wet zone. Subsequently, monthly rainfall data of each station were estimated using the data of surrounding stations based on the above selected methods so that actual data and the estimated data can be compared. Each estimated series was compared with the actual data series using different statistical comparison techniques. These comparisons include Descriptive Statistics of Error, Root Mean Square Error, Mean Absolute Percentage of Error and Correlation Coefficient. Results of the study show that the Inverse Distance method is the most suitable method for all three Low-country zones (wet, intermediate, and dry). However, for Mid-country and Upcountry Intermediate zones, Normal Ratio method is the most suitable method. Further, Arithmetic Mean method is more appropriate for Upcountry Wet zone while Aerial Precipitation Ratio method is more suitable for Mid-country Wet zone.

Keywords: Rainfall, Missing data, Arithmetic Mean method, Normal Ratio method, Inverse Distance method, Aerial Precipitation Ratio method

\section{INTRODUCTION}

Precipitation plays a significant role in agriculture and it is a major area in climatological studies (Ayoade, 1983). Studying about precipitation is important in (i) identifying precipitation characteristics; occurrence and temporal \& spatial variability (ii) statistical modeling and forecasting of precipitation and (iii) resolving the problems such as floods, droughts, land slides, etc. In tropics, the term rainfall has acquired the place of precipitation, where snow is generally absent and the term precipitation is interchangeable with rainfall. The consistency and continuity of rainfall data are very important in statistical analyses such as 
time series analysis. Both consistency and continuity may be disturbed due to change in observational procedure and incomplete records (missing observations) which may vary in length from one or two days to decades of years. However, inconsistency in a RF record can be identified by graphical or statistical methods such as Double mass curve analysis, the Von Neumann ratio test, cumulative deviations, likelihood ratio test, run test, etc. (Buishand, 1982). Nevertheless, filling of the gaps generated by inconsistent data is essential, and different procedures and approaches are available to accomplish this task. The most common method used to estimate missing rainfall data is Normal Ratio method (Chow et al, 1988). This method is based only on past observations of that rain gauge and surrounding gauges. However, there are other important factors such as distances among rain gauges, aerial coverage of each gauge etc., which are disregarded in this method but are proved to have significant influences on rainfall estimates. However, there are other techniques which use different other factors also to estimate missing rainfall data. This study focuses on few of them including Normal Ratio method, Inverse Distance method, and Arithmetic Mean method/ Local Mean method (Chow et al, 1988). The proposed Aerial Precipitation Ratio method by the authors looks at the area of influence of each surrounding gauge.

There are seven major climatic zones in Sri Lanka namely, Low-country wet zone, Low-country intermediate zone, Dry zone, Mid-country wet zone, Midcountry intermediate zone, Upcountry wet zone, and Upcountry intermediate zone (Agro-ecological map of Sri Lanka, 2003). The best method to estimate missing rainfall data can be different for each climatic zone depending on the rainfall pattern and spatial distribution.

\section{OBJECTIVES}

The main objective of the study is to identify the best method for specific climatic zone for the estimation of missing rainfall observations. The specific objectives of the research are to develop and introduce a new method for missing data estimation, compare and evaluate the estimates obtained from each method, and to study whether the suitability of each method varies with the factors like climatic zone, topography, distribution of rain gauges etc.

\section{MATERIALS AND METHODS}

The monthly rainfall data were used in this study. For each climatic zone, a cluster of four to five rain gauging stations was selected and altogether 31 stations were considered for the study (Table 01). Stratified random sampling method was used to select rain gauging stations for the study. The monthly rainfall data of selected stations were estimated using selected techniques based on the observations of surrounding stations. Details of data availability are given in Table 02 . In some of these stations, data for one or more years were missing.

In the analysis, all those years were excluded for all the stations within that cluster. In the instances where none or only few months had missing values, the averages of those particular months were used in place of missing data. In order to test the accuracy of methods used in estimation of missing data, a rain gauge station (X) and neighbouring stations, for which data 
are available, are selected and assumed that observations from $\mathrm{X}$ station are missing. Then using each method, observations for $\mathrm{X}$ station are estimated and compared with the actual observations.

Table 01: Selected Rain gauging stations and their locations

\begin{tabular}{|c|c|c|c|}
\hline \multirow{2}{*}{ Climatic Zone } & \multirow{2}{*}{ Rain gauging stations } & \multicolumn{2}{|c|}{ Location* } \\
\hline & & $\mathbf{X}(\mathbf{m})$ & Y (m) \\
\hline \multirow{5}{*}{$\begin{array}{l}\text { Upcountry wet } \\
\text { (WU) }\end{array}$} & Udaradella & 192000 & 196000 \\
\hline & Abbergeldie Group & 175800 & 191750 \\
\hline & Holmwood Estate & 193500 & 183500 \\
\hline & Seeta Eliya & 203250 & 192500 \\
\hline & Katukithula & 188000 & 209750 \\
\hline \multirow{5}{*}{$\begin{array}{l}\text { Upcountry } \\
\text { Intermediate } \\
\text { (IU) }\end{array}$} & Kurundu-Oya & 206500 & 208500 \\
\hline & Alma Estate & 206000 & 209750 \\
\hline & Gonapitiya Estate & 203000 & 205500 \\
\hline & Liddesdale & 209000 & 202500 \\
\hline & Maha Uva Estate & 209750 & 208750 \\
\hline \multirow{4}{*}{$\begin{array}{l}\text { Mid-country wet } \\
\text { (WM) }\end{array}$} & Rassagala Estate & 181500 & 166500 \\
\hline & Dethanagala Estate & 192000 & 171000 \\
\hline & Pettigala Estate & 188000 & 160750 \\
\hline & Alupola Estate & 177500 & 167500 \\
\hline \multirow{4}{*}{$\begin{array}{l}\text { Mid-country } \\
\text { Intermediate } \\
\text { (IM) }\end{array}$} & Kundasale Farm & 191500 & 232250 \\
\hline & Galphele (Wattegama) & 192122 & 237680 \\
\hline & Kandy Kings Pavillion & 185000 & 233500 \\
\hline & Delta Estate & 190000 & 222500 \\
\hline \multirow{4}{*}{$\begin{array}{l}\text { Low-country wet } \\
\text { (WL) }\end{array}$} & Agalawatta & 132000 & 148000 \\
\hline & Pimbura Estate & 133500 & 152750 \\
\hline & Bombuwela Agmet & 116000 & 153000 \\
\hline & Sirikandura Estate & 130500 & 144500 \\
\hline \multirow{4}{*}{$\begin{array}{l}\text { Low-country } \\
\text { Intermediate (IL) }\end{array}$} & Mapalana & 177000 & 95000 \\
\hline & Denagama & 186500 & 98500 \\
\hline & Thihagoda & 177848 & 89450 \\
\hline & Kamburupitiya & 177000 & 98000 \\
\hline \multirow{4}{*}{ Dry Zone (DL) } & Nachchaduwa & 166868 & 336500 \\
\hline & Mihintale & 172358 & 347480 \\
\hline & Anuradhapura & 156956 & 345284 \\
\hline & Maha-Illuppallama & 167000 & 322250 \\
\hline
\end{tabular}

* Location information is given using National Grid (Sri Lanka) based on Transverse Mercator Projection. 
Table 02: Availability of Rainfall data and Period of Data Availability

\begin{tabular}{|c|c|c|c|c|}
\hline \multirow{2}{*}{ Principle Station } & \multirow{2}{*}{$\begin{array}{c}\text { Used surrounding } \\
\text { stations }\end{array}$} & \multicolumn{3}{|c|}{ Years of data used } \\
\hline & & From & To & Years \\
\hline Udaradella (WU) & $\begin{array}{l}\text { Abbergeldie Group } \\
\text { Holmwood Estate } \\
\text { Seeta Eliya } \\
\text { Katukithula }\end{array}$ & 1976 & 1999 & 24 \\
\hline Kurundu-Oya (IU) & $\begin{array}{l}\text { Alma Estate } \\
\text { Gonapitiya Estate } \\
\text { Liddesdale } \\
\text { Maha Uva Estate }\end{array}$ & 1970 & 2000 & 28 \\
\hline Rassagala Estate (WM) & $\begin{array}{l}\text { Dethanagala Estate } \\
\text { Pettigala Estate } \\
\text { Alupola Estate }\end{array}$ & 1972 & 1999 & 28 \\
\hline & $\begin{array}{l}\text { Galphele (Wattegama) } \\
\text { Kandy Kings Pavillion } \\
\text { Delta Estate }\end{array}$ & 1979 & 1999 & 15 \\
\hline Agalawatta (WL) & $\begin{array}{l}\text { Pimbura Estate } \\
\text { Bombuwela Agmet } \\
\text { Sirikandura Estate }\end{array}$ & 1976 & 2000 & 25 \\
\hline Mapalana (IL) & $\begin{array}{l}\text { Denagama } \\
\text { Thihagoda } \\
\text { Kamburupitiya }\end{array}$ & 1971 & 1999 & 21 \\
\hline Nachchaduwa (DL) & $\begin{array}{l}\text { Mihintale } \\
\text { Anuradhapura } \\
\text { Maha-Illuppallama }\end{array}$ & 1970 & 1999 & 19 \\
\hline
\end{tabular}

\section{Arithmetic Mean method/ Local Mean method}

If the normal annual precipitations at surrounding gauges are within the range of $10 \%$ of the normal annual precipitation at station $\mathrm{X}$, then the Arithmetic procedure could be adopted to estimate the missing observation of station X (Chow et al, 1988). This assumes equal weights from all nearby rain gauge stations and uses the arithmetic mean of precipitation records of them as estimate (Tabios \& Salas, 1985).

\section{Normal Ratio method}

This method is used if any surrounding gauges have the normal annual precipitation exceeding $10 \%$ of the considered gauge. This weighs the effect of each surrounding station (Singh, 1994). The missing data are estimated by, 


$$
\boldsymbol{P}_{X}=\frac{1}{m} \sum_{i=1}^{m}\left[\frac{N_{X}}{N_{i}}\right] P_{i}
$$

where,

$\mathrm{P}_{\mathrm{X}}=$ Estimate for the ungauged station

$\mathrm{P}_{\mathrm{i}}=$ Rainfall values of rain gauges used for estimation

$\mathrm{N}_{\mathrm{x}}=$ Normal annual precipitation of $\mathrm{X}$ station

$\mathrm{N}_{\mathrm{i}}=$ Normal annual precipitation of surrounding stations

$\mathrm{m}=$ No. of surrounding stations

\section{Inverse Distance method}

In this method, weights for each sample are inversely proportionate to its distance from the point being estimated (Lam, 1983).

where,

$$
\boldsymbol{P}_{X}=\frac{\sum_{i=1}^{N} \frac{1}{d^{2}} p_{i}}{\sum_{i=1}^{N} \frac{1}{d^{2}}}
$$

$\mathrm{P}_{\mathrm{x}}=$ estimate of rainfall for the ungauged station

$\mathrm{P}_{\mathrm{i}}=$ rainfall values of rain gauges used for estimation

$\mathrm{d}_{\mathrm{i}}=$ distance from each location the point being estimated

$\mathrm{N}=$ No. of surrounding stations

\section{Aerial Precipitation Ratio method}

This method was developed based on spatial distribution of daily rainfall without accounting for the historical recurrence. The method leads the extension of point rainfall records to Thiessen Polygon areas. The APR method assumes the contribution of rainfall from surrounding stations is proportionate to the aerial contribution of each sub catchment (Thiessen polygon area claimed by each station without considering the missing gauge), when the station of missing values is excluded (De Silva, 1997).
The formula of the method can be given as follows.

$$
P_{X}=\frac{\sum_{i=1}^{N}\left[\left(A_{j}-A_{i}\right) P_{i}\right]}{\sum_{i=1}^{N}\left(A_{j}-A_{i}\right)}
$$

$\sum_{i=1}^{N}\left(A_{j}-A_{i}\right)=$ Thiessen Polygon area values

$\mathrm{A}_{\mathrm{j}}=$ Thiessen Polygon area when station with missing values is excluded

$$
\mathrm{A}_{\mathrm{i}}=\text { Thiessen Polygon }
$$

area when station with missing values is included

$\mathrm{P}_{\mathrm{i}}=$ annual precipitation of surrounding stations

$\mathrm{P}_{\mathrm{x}}=$ estimate for monthly rainfall for the station with missing observations

\section{Comparison of Estimates}

The estimates obtained from each method are compared with actual records. The suitability of method is decided by how close the estimates and actual values are in a given time series. Several 'Descriptive statistics of error' can be used as criteria to estimate the closeness of estimated and actual values. These Descriptive statistics of error include Mean ( $\mu$ ), Standard Deviation (S), Correlation Coefficient (r), Root Mean Square Error (RMSE), Mean Absolute Percentage (MAPE).

\section{RESULTS AND DISCUSSION}

\section{Error Means and Error Standard Deviations (SD)}

Among Descriptive Statistics of Error or deviation between actual value and estimate, Error Mean is the representative value of the error. The SD of Error indicates the fluctuations 
of the deviations. The Error Means and Error SDs are presented in Table 03. The minimum error mean and minimum SD for all low country stations were recorded for Inverse Distance (ID) method. Both Intermediate zone stations (IU \&IM) recorded minimum mean as well as minimum SD for Normal Ratio (NR) method. Records of WU and WM zones had no clear pattern like above and minimum mean and SD for WU were given by arithmetic mean (AM) method and minimum mean and minimum SD for WM were given by Aerial Precipitation Ratio (APR) method.

\section{Root Mean Square Error (RMSE)}

This also shows similar results to Mean and SD of error as shown in Table 04 . Low country zones (WL, IL, and DL) gave least RMSE for ID method. Mid country and up country Intermediate zones gave minimum RMSE when estimated by NR method. Being similar to Mean and SD of error, minimum RMSE for WU was given by arithmetic mean (AM) method and minimum RMSE for WM was given by Aerial Precipitation Ratio (APR) method.

\section{Correlation Coefficient}

This is an indicator for the strength of the relationship between observations and estimates. Higher positive coefficients indicate that estimates will be high or low when actual is high or low respectively giving evidence about the suitability of estimation method. The correlation coefficients of each method studied are given in Table 05 . The results of this parameter also agreed with the results of descriptive statistics of the error and RMSE. For all low country stations (WL, IL and $\mathrm{Dl})$ the highest Correlation coefficient was resulted with ID method. Two intermediate zones (WU and IU) recorded maximum values for NR method. WU and WM showed highest Correlation Coefficients by arithmetic mean (AM) method and Aerial Precipitation Ratio (APR) method, respectively.

\section{Mean Absolute Percentage Error (MAPE)}

This indicates the deviation of the estimate value from the observed (actual) value with respect to the observed value. The calculated MAPE values are given in Table 06. WU, IM, and DL gave minimum values for Normal Ratio method while WL and IU gave minimum value for Inverse Distance method. The WM and IL zones gave minimum values for Aerial Precipitation Ratio method and Arithmetic Mean method, respectively. According to the results of MAPE, it does not give any clear pattern in suitability of methods for different zones. 
Table 03: Error means and Error Standard Deviations for each method for seven climatic zones

\begin{tabular}{ccccccccc}
\hline & \multicolumn{2}{c}{ AM method } & \multicolumn{2}{c}{ NR method } & \multicolumn{2}{c}{ ID method } & \multicolumn{2}{c}{ APR method } \\
\cline { 2 - 9 } & $\begin{array}{c}\text { Error } \\
\text { Mean }\end{array}$ & $\begin{array}{c}\text { Error } \\
\text { SD }\end{array}$ & $\begin{array}{c}\text { Error } \\
\text { Mean }\end{array}$ & $\begin{array}{c}\text { Error } \\
\text { SD }\end{array}$ & $\begin{array}{c}\text { Error } \\
\text { Mean }\end{array}$ & $\begin{array}{c}\text { Error } \\
\text { SD }\end{array}$ & $\begin{array}{c}\text { Error } \\
\text { Mean }\end{array}$ & $\begin{array}{c}\text { Error } \\
\text { SD }\end{array}$ \\
\hline WU & 66.01 & 65.18 & 69.25 & 73.06 & 68.52 & 68.83 & 67.66 & 69.04 \\
WM & 80.42 & 82.13 & 80.43 & 75.56 & 82.65 & 78.30 & 75.94 & 75.46 \\
WL & 65.12 & 54.25 & 53.64 & 50.49 & 52.41 & 48.03 & 53.99 & 48.51 \\
IU & 61.69 & 80.74 & 50.03 & 79.20 & 65.27 & 87.40 & 63.08 & 81.69 \\
IM & 69.38 & 56.23 & 34.62 & 31.63 & 64.64 & 52.12 & 61.10 & 50.88 \\
IL & 55.42 & 65.39 & 53.53 & 64.14 & 51.26 & 57.57 & 57.44 & 69.63 \\
DL & 41.76 & 56.56 & 37.86 & 52.78 & 36.82 & 51.30 & 41.84 & 56.50 \\
\hline
\end{tabular}

Table 04: Root Mean Square Error for each method for seven climatic zones

\begin{tabular}{|c|c|c|c|c|}
\hline Climatic Zone & AM method & NR method & ID method & APR method \\
\hline WU & 92.6919 & 100.574 & 97.0357 & 96.586 \\
\hline WM & 114.853 & 110.278 & 113.771 & 106.973 \\
\hline WL & 84.7020 & 73.6101 & 71.0394 & 72.5278 \\
\hline IU & 100.299 & 94.8881 & 108.982 & 103.11 \\
\hline IM & 89.2114 & 46.8298 & 82.9418 & 79.4189 \\
\hline IL & 85.6193 & 83.4512 & 76.9957 & 90.1547 \\
\hline DL & 70.2076 & 64.8595 & 63.0503 & 70.2026 \\
\hline
\end{tabular}

Table 05: Correlation Coefficients for each method for seven climatic zones

\begin{tabular}{|c|l|l|l|l|}
\hline Climatic Zone & \multicolumn{1}{|c|}{ AM method } & \multicolumn{1}{|c|}{ NR method } & \multicolumn{1}{|c|}{ ID method } & \multicolumn{1}{|c|}{ APR method } \\
\hline WU & 0.83898 & 0.83213 & 0.83137 & 0.82786 \\
\hline WM & 0.83042 & 0.82113 & 0.80257 & 0.834 \\
\hline WL & 0.94461 & 0.9414 & 0.95016 & 0.94744 \\
\hline IU & 0.89463 & 0.89596 & 0.87184 & 0.88539 \\
\hline IM & 0.84837 & 0.8615 & 0.85863 & 0.85731 \\
\hline IL & 0.79414 & 0.80579 & 0.83211 & 0.7758 \\
\hline DL & 0.78208 & 0.78221 & 0.78258 & 0.78191 \\
\hline
\end{tabular}

Table 06: Mean Absolute Percentage Error for each method for seven climatic zones

\begin{tabular}{|c|c|c|c|c|}
\hline Climatic Zone & AM & NR & ID & APR \\
\hline WU & 86.7516 & 76.1584 & 85.2407 & 84.0986 \\
\hline WM & 35.6984 & 42.3452 & 37.1841 & 34.3058 \\
\hline WL & 21.9117 & 20.9618 & 18.6136 & 19.2974 \\
\hline IU & 48.6153 & 50.6863 & 47.1127 & 49.5192 \\
\hline IM & 118.534 & 64.5799 & 115.905 & 115.147 \\
\hline IL & 46.9635 & 50.0270 & 48.8454 & 51.3612 \\
\hline DL & 110.575 & 88.6641 & 96.1255 & 110.223 \\
\hline
\end{tabular}




\section{CONCLUSIONS}

In estimating missing rainfall data, for Low country stations (WL, IL \& DL) Inverse Distance method is the most suitable method among the methods studied. For Mid country and Upcountry Intermediate Zone stations (IM \& IU), Normal Ratio method is the most suitable method compared to other three methods. Arithmetic mean method is more suitable for Upcountry Wet Zone and Aerial Precipitation Ratio method is more suitable for Mid country Wet Zone. The degree of suitability of these estimation methods for each zone needs to be determined and validated by further studies.

\section{References}

Ayoade, J O. (1983). Introduction to Climatology for the Tropics. John Wiley and Sons: New York.

Buishand T A. (1982). Some methods for testing the homogeneity of rainfall records. Journal of Hydrology. 58: 11-27.

Chow V.T., Maidment D.R. and L.W. Mays (1988). Applied Hydrology, Mc Graw Hill Book Company, ISBN 0-07-010810-2.

De Silva R P. (1997). Spatiotemporal Hydrological Modeling with GIS for the Upper Mahaweli Catchment, Sri Lanka. PhD Thesis (Unpublished), Silsoe Campus, Cranfield University, UK.

Lam N S. (1983). Spatial Interpolation Methods review. The American Cartographer. 10: $129-149$.

Singh V P. (1994). Elementary Hydrology. Prentice Hall of India: New Delhi.

Tabios G. Q. and Salas J. D. (1985). A comparative analysis of techniques for spatial interpolation of precipitation. Water Resource Bull. 21(3), 365-380. 